\title{
Circular RNA Circ_0025033 Promotes the Evolvement of Ovarian Cancer Through the Regulation of miR-330-5p/KLK4 Axis [Retraction]
}

Cheng H, Wang N, Tian J, Li Y, Ren L, Shi Z. Cancer Manag Res. 2020;12:2753-2765.

At the authors request, the Editor and Publisher of Cancer Management and Research wish to retract the published article. The authors have informed the journal that no ethical approval was given by the ethics committee of the Institute Review Ethics Committee of Huaihe Hospital of Henan University, despite the article stating such approval had been provided. Given this serious breach of our editorial polices the authors decided to retract the paper.

Our decision-making was informed by our policy on publishing ethics and integrity and the COPE guidelines on retraction.

The retracted article will remain online to maintain the scholarly record, but it will be digitally watermarked on each page as "Retracted".

\section{Publish your work in this journal}

Cancer Management and Research is an international, peer-reviewed open access journal focusing on cancer research and the optimal use of preventative and integrated treatment interventions to achieve improved outcomes, enhanced survival and quality of life for the cancer patient.
The manuscript management system is completely online and includes a very quick and fair peer-review system, which is all easy to use. Visit http://www.dovepress.com/testimonials.php to read real quotes from published authors. 